\title{
scripted
}

Volume 17, Issue 1, January 2020

\section{Book review: Research Handbook on Global Health Law}

Gian Luca Burci and Brigit Toebes (eds)

Cheltenham: Edward Elgar Publishing, 2018. 576 pages.

ISBN: $9781785366536 . £ 170$.

Reviewed by Edward S. Dove*

(ㄷ) (1) $\circledast \Theta$

(C) 2020 Edward S. Dove

Licensed under a Creative Commons Attribution-NonCommercial-

NoDerivatives 4.0 International (CC BY-NC-ND 4.0) license

DOI: $10.2966 /$ scrip. 170120.185

* Lecturer in Health Law and Regulation, School of Law, University of Edinburgh. 
Global health law is an emerging subdiscipline within law that is concerned with the study of how law, broadly defined, can impact negatively or positively the health of populations across the globe. As is the case with the term "global health", there is no universally accepted definition, particularly given its still nascent stage of development. In a ground-breaking article from 2008, Gostin and Taylor offered the following definition:

Global health law is a field that encompasses the legal norms, processes, and institutions needed to create the conditions for people throughout the world to attain the highest possible level of physical and mental health. The field seeks to facilitate health-promoting behaviour among the key actors that significantly influence the public's health, including international organizations, governments, businesses, foundations, the media, and civil society. The mechanisms of global health law should stimulate investment in research and development, mobilize resources, set priorities, coordinate activities, monitor progress, create incentives, and enforce standards. Study and practice of the field should be guided by the overarching value of social justice, which requires equitable distribution of health services, particularly to benefit the world's poorest populations. ${ }^{1}$

This definition is politically orientated (or some would argue muddled), combining descriptive and normative elements. It views law instrumentally - a means to improve people's health. Other definitions may be more politically neutral. A common denominator across all is the analytical focus on international or transnational legal norms, processes, and institutions. Global health law asks: in what ways do these legal norms, processes, and institutions advance or thwart 
the health of the global community? We might claim that global health shares the same objectives as public health, the principal one of which is to improve the health and wellbeing of populations, albeit on a larger scale without necessitating a specific focus on geographic borders. While it has some elements that are the same as in the domestic public health context, global health is more concerned with coordination, capacity-building, the equitable distribution of health knowledge around the world, and the equal achievement of health across borders. Therefore, a large part of global health's concern has been for populations in lower- and middle-income (LMIC) countries, where public health and public health institutions and systems are on the whole less developed and often under-resourced.

As an emerging subdiscipline within law, a number of articles and books have been published in recent years that map the terrain, attempting to carve out an epistemological space. The Research Handbook on Global Health Law, part of Edward Elgar's Research Handbooks on Globalisation and the Law, is a worthy addition to this literature. The editors, Gian Luca Burci, an Adjunct Professor of Law at the Graduate Institute of International and Development Studies in Geneva, and Brigit Toebes, Professor of Health Law in a Global Context at the University of Groningen, demonstrate a refreshing degree of candour about the difficulty in mapping the conceptual terrain in global health law. As they confess: "The more we advanced with our Handbook, the less confident we became about the conceptualization of global health law as a branch of international law. We must now conclude that global health law is a highly fragmented field with undefined boundaries and parameters. We are unsure whether we can call it an existing branch of public international law, or rather a systematic approach to the normative role of health in international law and an aspiration for those who engage with this field" (p. xiii). 
Ultimately, what this Handbook does so well is provide a set of wellresearched and well-written contributions from leading global health law scholars that stake modest but innovative claims about what global health law is and how it may contribute to improving the population's health.

The book is organised across three parts: 1) framing global health law; 2) international law and health; and 3) international regulation of health challenges. In the interest of space, I will select and discuss four chapters that I consider especially outstanding. The two chapters comprising Part 1 deserve particular praise.

In Chapter 1 ("Global Health Law: Defining the Field"), Brigit Toebes asks and answers fundamental questions about the scope, nature, and normative foundations of global health law. Toebes labels global health law a field of international law - though of course she later expresses some reservation about this label in the preface. In her view, global health law "consists of a limited set of binding and non-binding instruments adopted in the framework of the World Health Organization, in an interaction with both hard and soft law standards recognized in other branches of international law, including human rights law, international humanitarian law, international environmental law, international trade, property and investment law" (pp. 2-3). This definition seems rather narrow; it risks viewing the field as not much more than a repository of WHO instruments and regional and sub-regional frameworks. I would prefer to view global health law more broadly and view "law" as open-ended enough to encompass regulatory, governance, and policy tools and approaches from a variety of state and non-state actors. Toebes does seem to recognise the value of a more flexible interpretation, too, admitting that "...soft law standards may play a significant normative and regulatory role in global health law" (p. 4). Toebes also argues that human rights are a core concern in global health law; many scholars situate their analyses of health issues within the human "right to health" 
and of the field of "health and human rights" in global health law. As she says, "Potentially, the right to health may feature as a core, unifying standard in the field" (p. 15). While I disagree with some of Toebes's conceptual stances and I'm not convinced that the right to health will feature as a core, unifying standard in global health law, without question this is a chapter that should be assigned reading in any global health law course that explores the conceptual underpinnings of the field.

Chapter 2 ("Global Health Law and Governance: Concepts, Tools, Actors and Power") is also an excellent conceptual contribution to literature. Here, Surie Moon of the Harvard T.H. Chan School of Public Health charts global health law within the broader context of global governance processes affecting health. She argues that global health law can be viewed as a tool wielded by different actors to shape processes of global governance; similarly, law can be both an outcome of and input to governance processes. Importantly, she notes that relevant actors in global health include state (national and IGO) and non-state actors (e.g. civil society groups, think tanks, academics, NGOs). In her view, global health law is somewhat technically defined as "a codified rule (whether binding or nonbinding) with the explicitly-stated intention to protect or promote health, endorsed by a governmental or intergovernmental entity, agreed by three or more countries and with effects beyond a single region" (pp. 35-36). One of the most original and innovative parts of her chapter is the taxonomy of tools and mechanisms for global governance, among which global health law is one. Moon identifies seven tools and mechanisms of global governance: codified formal and informal rules; normative claims; decision-making processes; accountability mechanisms; ideational/framing tools; resource mobilisation; and physical force (threat or use). Moon also identifies seven types of power that operate in global governance processes: compulsory; economic; structural; institutional; normative; expert; and discursive. Moon has done a great service to the global 
health law community in this conceptual mapping work; policymakers in particular should pay close attention to this chapter for what it offers in the way of better understanding global health law as a governance tool to meet health challenges.

In Chapter 4 ("Hardwired Human Rights: A Health and Human Rights Perspective on Global Health Law"), Therese Murphy of Queen's University Belfast takes a critical perspective on Georgetown Law Professor Lawrence Gostin's pioneering Global Health Law textbook, which was published in 2014. ${ }^{2}$ Though appreciative of Gostin's significant intellectual contribution to global health, she articulates concern with the way in which Gostin "contours human rights, on the one hand, and law on the other" (p. 83), specifically, the way in which his book positions economic and social rights, and the human right to health especially.

In his book, Gostin claims that socio-economic human rights are beset by deficiencies that "will be hard to overcome" and that the flaws in socio-economic rights are "inherent", namely, they suffer from imprecise standards. Murphy argues that it is misleading and damaging to single out economic and social rights as imprecise, realisable only on a progressive basis, and characterized by weaknesses in enforcement. As she points out, the wording of all types of human rights is imprecise. Similarly, resource constraints and priority setting are issues in all rights. Murphy also takes issue with Gostin's view of the right to health as more a collective than individual right; here, she is concerned that this view can be a dangerous justification for the state to interfere with individual rights, and can unduly ignore the important role of individuals' rights in the more intimate clinical setting. More broadly, Murphy expresses concern with Gostin's 
positioning of law: she thinks the positioning is at once both too grand and too limited - it inflates our expectations of what law can do, while also not being expansive and exacting enough of what law is such that it can meet those expectations in practice. In other words, law is set up to disappoint. Gostin's framing of international human rights law neglects to discuss how it works in non-law settings and how it interacts with other fields, especially normative fields such as ethics, morality, and politics. Gostin's criticisms of law and international human rights law "draw from too narrow a sense of law - in essence, from law on the books - which means they miss detail that is crucial, and this in turn encourages fatalism, nihilism even, about law. Combined with the expectations generated by global health law, they leave us with a deeply misshapen horizon" (p. 100).

Murphy does not just criticise, though; she also offers an alternative view on how we should view the relationship of global health law and human rights. Rather than merely list the "obvious flaw" of socio-economic rights, Murphy suggests that instead we make "a commitment to inquiry: a commitment, for instance, to more scholarly engagement with state and NGO practice during human rights treaty body hearings and the Universal Periodic Review" (p. 97). She proposes that scholars undertake a "more intelligent critique of law and international human rights law, a critique that understands law as law" (p. 100); and better appreciate the pluralistic nature of international human rights law (p. 101). She suggests "hardwiring" human rights and human rights law, by which she means that we should commit ourselves "to the exciting but genuinely challenging work of understanding how rights work in practice across both law and non-law settings" (p. 103). Given the intellectual rigour and nuance of her argument, Murphy's chapter should be assigned reading as a counter-narrative to Gostin's leading book. 
The fourth and final chapter I wish to praise is the concluding Chapter 16 ("Global Health Law: Present and Future") from Gian Luca Burci. Here, Burci does fantastic work linking his chapter with the others in the book, while outlining the normative landscape on health, including non-binding instruments and binding instruments adopted by the $\mathrm{WHO}$ and other international organisations, where the main purpose is to protect or promote particular aspects of human health. Burci argues that a number of recent developments "have awakened scholarly and political attention to the implications of international legal and policy frameworks on health and the need to construe an effective normative response to safeguard and preserve national regulatory space to protect and promote health" (p. 494). These developments include the impact of globalisation on health and the growing perception of the increasing role of health considerations in development, economic, environmental, and security agendas; it also includes the HIV/AIDS pandemic that propelled health concerns to a high level of international attention. Both developments have led to calls for a need to improve health outcomes in the implementation and enforcement of existing law, as well as calls for new health treaties. These new health treaties can be organised around addressing three major challenges to global health: 1) the fight against communicable diseases, in particular emerging and re-emerging disease, often of a zoonotic nature; 2) prevention and control of noncommunicable diseases; and 3) the perceived failure of current global governance frameworks, in particular the pharmaceutical market, to deliver equitably essential products and services perceived as public goods for the survival of a large proportion of humanity. Burci is not politically naïve; he rightly acknowledges that "proposals for new health treaties seem to get no political traction, at least as of the time of writing this chapter. The visible trends in policymaking seem to be in favour of pursuing solutions based on either soft normative instruments, coordination frameworks through international institutions and/or 
acting within existing international hard law norms" (p. 508). As he concludes: “...it is difficult to foresee grand and ground-breaking developments or reforms of the overall global health law system under present circumstances, but rather a continuation of the current normative trends and an increase in their complexity" (p. 528).

Grounded in realism but driven by optimism, it is hard to finish reading this book without a painful recognition that we have much work to do still in harnessing law to create the conditions for people throughout the world to attain the highest possible level of physical and mental health. Even as global living standards rise, we remain mired in significant health challenges across the globe, from acute health crises in Venezuela and Yemen, to worsening air pollution, weak primary health care, and growing antimicrobial resistance in many regions. Addressing these global health challenges requires a multinational, multipronged sustained effort over the long haul. Law is a crucial instrument to employ in addressing these challenges. Burci and Toebes have put together an excellent series of contributions from the leading thinkers in global health law today that help us consider the ways in which we can employ the law, and also the ways in which the law is limited. Law cannot do all of the work; as Murphy reminds us, we must equally be attuned to normative fields such as ethics, morality, and politics. Those who work, research, and teach in the field should read and teach from this book for many years to come. 